\title{
Connecting With Social Media: Using Instagram in Introductory Accounting to Enhance Student Engagement and Performance
}

\author{
Christie M. Novak \\ Le Moyne College
}

\begin{abstract}
This paper discusses ways to engage students in accounting outside of the classroom on a resource they're already using, Instagram. Instagram can be used for a variety of activities, including practice questions to keep them thinking about accounting outside of class and interviews with professionals to share experiences with students that they wouldn't otherwise be able to have in a classroom. By interviewing professionals and sharing their perspectives and experiences, insight and value are added to the course. After a semester of using Instagram in the introductory accounting course, survey data from students in the course stated they found it unique, engaging, and a fun way to interact with accounting and engage in the course material. Nearly 92 percent of the respondents involved in the Instagram activity agreed that it should continue to be used in the course.
\end{abstract}

Keywords: Instagram, social media, introductory accounting, engagement

\section{INTRODUCTION}

As educators, we want students to learn the course material and perform well in our classes, and we hope that our course will be an enjoyable learning experience for them. One way to assist in the learning process is to keep students actively engaged (Bryson \& Hand, 2007). Chapman (2003) offers a definition of engagement as "students' cognitive investment in, and active participation in, and emotional commitment to their learning". Kuh, Kinzie, \& Buckley (2006) define engagement as "the extent to which they take part in educationally effective practices". Both definitions focus on the amount of active effort a student puts into their learning. Student engagement is one of variables that has a positive effect on student achievement and academic performance (Carini, Kuh, \& Klein, 2006; Coates, 2005; Lee, 2014). It is a contributing factor to student performance, and "the research on student engagement is clear - a more engaged student is a more successful student" (Junco, 2012). Students perform well in a course when they are actively engaged in the learning process. The more engaged they are in learning, the more they learn (Kuh, 2003). Kuh, Kinzie, \& Buckley (2006) conclude from the results of three national surveys that student engagement is positively linked to student performance and success. It is important for us as educators to help our students learn the course material and perform well in the course. One way to facilitate their learning is to keep them actively engaged.

A new avenue to investigate related to student engagement is the use of social media platforms to assist in building engagement. There has been much research into new methods to engage students through the use of social media platforms (Arquero \& Romero-Frías, 2013; Clements, 2015; D’Aquila, Wang, \& Mattia, 2019; Dyson, Vickers, Turtle, Cowan, \& Tassone, 2015; Holmes \& Rasmussen, 2018; Junco, Elavsky, \& 
Heiberger, 2013; Junco, Heiberger, \& Loken, 2011; Khan, Kend, \& Robertson, 2016; Paul, Baker, \& Cochran, 2012; Roblyer, McDaniel, Webb, Herman, \& Witty, 2010; Sheeran \& Cummings, 2018). In addition to investigating the correlation between social media and engagement, researchers have also studied the impact of social media on academic performance (Al-Bahrani \& Patel, 2015; Arquero \& Romero-Frías, 2013; Cain \& Policastri, 2011; Clements, 2015; D’Aquila et al., 2019; Dabbagh \& Kitsantas, 2012; Dyson et al., 2015; Evans, 2014; Holmes \& Rasmussen, 2018; Junco, 2012; Junco et al., 2013; Khan et al., 2016; Kirschner \& Karpinski, 2010; Lambić, 2016; Lowe \& Laffey, 2011; Paul et al., 2012; Top, 2012; Yu, Tian, Vogel, \& Chi-Wai Kwok, 2010). However, there are conflicting results as to the effectiveness of social media on student engagement and academic performance. Some students view the academic use of social media as a double-edged sword: "having the potential to both inform and distract" (Smith, 2016). Particular attention has been given to using Facebook, with some studies incorporating the use of Twitter (Junco et al., 2011; Lowe \& Laffey, 2011), Pinterest (Holmes \& Rasmussen, 2018), or YouTube (Bosch, 2009; D’Aquila et al., 2019). There is very little understanding of the impact of Instagram on student engagement. To my knowledge, there is only one other paper investigating the use of Instagram as coursework (Sakr, 2019); however, this paper uses Instagram in an Education Studies program with the outcomes focused on liberatory theorizing, not student engagement or performance. This is an opportunity to investigate the impact that social media, specifically Instagram, has on student engagement and performance.

This paper will describe the activities done throughout a semester using Instagram as a social media platform in the Introductory Accounting class. Instagram was used to engage students in the material after class, create meaningful and helpful conversations with students about their understanding of the content, and share professionals' experiences in both public and private accounting. This was an optional activity where students could follow the professor on Instagram with bonus points awarded after the completion of content-based activities. The purpose of the activity was to create a unique and fun way to share knowledge about accounting in a setting that was both familiar and easily accessible to students.

The remainder of the paper is organized as follows. The next section is a literature review of the use of social media as an educational tool. Next is a detailed description of the Instagram activity with activity goals and a plan for use throughout the semester. The following section provides evidence of the impact of the activity and discusses student perceptions of the assignment. The next section discusses limitations and suggestions for future research. The final section offers a conclusion of the findings.

\section{LITERATURE REVIEW}

\section{Differences Between Discussion Board Postings and Social Media}

There are a few differences between using social media for conversation in a course and using a discussion board. First, students find it easier to communicate and create conversations on a social media platform (Khan et al., 2016). They already are familiar with the workings of a platform because they use it frequently in their personal lives. Students cite the convenience of using social media as an advantage over traditional discussion boards or LMS postings (Clements, 2015; Hurt et al., 2012; Khan et al., 2016). Second, they are on social media frequently throughout the day and are unlikely on a Learning Management System as frequently. Generation Z spends about three hours per day on social media (GlobalWebIndex, 2019). In the Khan et al. (2016) study of accounting students, they found that $31 \%$ of respondents spent more than 15 hours per week on social media. An advantage of using social media for educational purposes is to meet them where they're already spending their time. For many of our students, that means on social media platforms. Finally, social media allows them to be informal. Bosch (2009) found that Facebook was perceived to be a shared space, meaning that it was not controlled by either the students or professor. Students viewed this shared space as breaking down the traditional power hierarchies and were more comfortable (Bosch, 2009). Many discussion boards are graded on their own or somehow integrated into the course grade. Even if they're not an official part of the grade, they're monitored by the professor, which gives the perception of continuing the classroom power structure. Social media, however, is a platform that was created to be informal. It allows students space to attempt a problem, ask questions, and make mistakes, 
knowing it won't negatively impact their course grade. Hollyhead, Edwards, \& Holt (2012) found that students prefer to use social networking sites to communicate with other students and develop peer groups. Some of my students reiterated these feelings in their qualitative feedback. One said, "I think it is a good way to have a conversation with students and professor". Another noted, "I think that using Instagram was a great new way to connect with students". For the intent of enhancing engagement in a course, social media provides a new and interesting platform to use.

\section{The Use of Social Media for Educational Purposes}

Using social media as an educational tool can add value to a course by engaging students in the course material outside of the classroom. Participants in an introductory accounting course noted that lectures were not engaging and suggested the use of "content not found in the textbook", "real-world examples", and "videos that connect to the material" to enhance student engagement (Abbott \& Palatnik, 2018). Integrating social media into a course can provide a way to include some of those suggestions through links and posts. Clements (2015) found that using Facebook in a course as an educational tool can be used to enhance student engagement and then additionally found a significant relationship between academic performance and the level of academic engagement. Lowe \& Laffey (2011) encouraged students to use Twitter during their marketing course. They found that $65 \%$ of students volunteered to use Twitter, and the responses from students were positive (Lowe \& Laffey, 2011). They found a positive relationship with the use of Twitter and both learning and enjoyment of the course (Lowe \& Laffey, 2011). Holmes \& Rasmussen (2018) gave students a Pinterest assignment throughout the semester and found increased student engagement and interest in managerial accounting. Hornik \& Thornburg (2010) used the virtual reality platform Second Life $^{\mathrm{TM}}$ to help students learn the material in an introductory accounting class. They found a significant, positive relationship between engagement and the first exam score after controlling for internet use, GPA, age, and gender (Hornik \& Thornburg, 2010). In the survey based paper of students' perceptions of the use of social media as an educational platform, Smith (2016) found that students believe the use of social media is successful in supporting their learning.

Hurt et al. (2012) performed a study where two sections of a course used Facebook and two sections used eLC for their discussion board postings. Students using Facebook reported the ease, convenience, and social connectivity felt by students. They noted "Facebook's easy-to-use and aesthetically appealing interface could also help students navigate many of the common barriers to online discussion participation" (Hurt et al., 2012). They also found that many of the attributes of the study, such as "getting to know others in the class, learning course material, shaping the way students think about subject matter, and feeling like a valued participant in the course" received higher ratings from students in the Facebook groups those in eLC (Hurt et al., 2012).

Khan, Kend, and Robertson (2016) found in their survey of accounting students varying advantages of using social media, such as the "breadth of information", "access to different perspectives", and being more interesting and engaging. Students also cited "the ability to initiate conversations more easily" as an advantage of using social media. They found that $74 \%$ of students in the survey used social media for academic-related purposes, and of those students, 90\% would continue to do so (Khan et al., 2016). They also found a significant relationship between GPA and the use of social media for academic purposes (Khan et al., 2016). There is a vast amount of research to support that students are comfortable using technology and social media to enhance their educational experience.

However, not all research of social media concludes that it positively affects students academically. In Gettman \& Cortijo's (2015) study of college students, they found that students were generally strongly against using Facebook for academic purposes. They found students to be most uncomfortable with the use of Facebook when the professor had access to the Facebook group and in friending their professor on Facebook (Gettman \& Cortijo, 2015). However, 54\% of the students in the study reported using Facebook for academic purposes, like communicating for group projects (Gettman \& Cortijo, 2015). They noted many of the students who started with positive comments about the use of Facebook in class largely followed up with a "but.." and some negative comments (Gettman \& Cortijo, 2015). Based on their study of 245 college students, it appears that students are willing to use Facebook for academic purposes but are not comfortable 
when the professor is involved. Students' major concerns were with privacy and keeping their academic and social lives separate (Gettman \& Cortijo, 2015). Professors also seem rather uncomfortable with using social media platforms for something other than social networking. Manca \& Ranieri (2016) found in their survey of over 6,000 Italian professors that scholars were hesitant to adopt social media for academic purposes and were more comfortable using them socially. Only 13\% of the students surveyed in Gettman \& Cortijo's (2015) study had a professor use Facebook for a college class. It is unclear as to whether the use of social media in a classroom will have a positive or negative effect on student perception of the course and student engagement. With such mixed results on the impact of social media on student engagement, it is important to continue research on the use of social media.

It is also important to include more than one type of social media in the literature. Much of the previous research has focused on Facebook (see Bosch, 2009; Cain \& Policastri, 2011; Clements, 2015; Dyson et al., 2015; Gettman \& Cortijo, 2015; Hurt et al., 2012; Junco, 2012; Khan et al., 2016; Kirschner \& Karpinski, 2010; Lambić, 2016; Paul et al., 2012; Roblyer et al., 2010; Wang, Woo, Quek, Yang, \& Liu, 2012), but that is not the only social media platform available. Other social media platforms are becoming more popular. There is even less known about the impact on student engagement while using these other social media platforms. Table 1 compares five of the commonly used social media platforms - Instagram, Facebook, Snapchat, Twitter, and Pinterest. While 89 percent of Gen Z's have a Facebook account, nearly 80 percent visit or use Instagram, with nearly 75 percent of them using Instagram on a monthly basis (GlobalWebIndex, 2019). Instagram is third in top social platforms used by Gen Z, only slighted by Facebook and YouTube (GlobalWebIndex, 2019). Instagram is a popular social media platform and provides a viable and new opportunity to engage students that warrants further research.

\section{TABLE 1}

\section{COMPARISON OF SOCIAL MEDIA PLATFORMS}

\begin{tabular}{|c|c|c|c|c|c|}
\hline Platform & Instagram & Facebook & Snapchat & Twitter & Pinterest \\
\hline Information & $\begin{array}{l}\text { Stories and } \\
\text { posts can be } \\
\text { saved }\end{array}$ & $\begin{array}{l}\text { Information } \\
\text { saved to the } \\
\text { wall but may } \\
\text { get lost over } \\
\text { time }\end{array}$ & $\begin{array}{l}\text { No information } \\
\text { can be saved } \\
\text { for the student } \\
\text { to view later }\end{array}$ & $\begin{array}{l}\text { Information } \\
\text { saved but may } \\
\text { get lost over } \\
\text { time }\end{array}$ & $\begin{array}{l}\text { Information } \\
\text { saved to the } \\
\text { board but may } \\
\text { get lost over } \\
\text { time }\end{array}$ \\
\hline Discussions & $\begin{array}{l}\text { Both course- } \\
\text { wide and } \\
\text { one-on-one } \\
\text { discussions }\end{array}$ & $\begin{array}{l}\text { Mostly course- } \\
\text { wide } \\
\text { discussions } \\
\text { with the ability } \\
\text { to create one- } \\
\text { on-ones }\end{array}$ & $\begin{array}{l}\text { Only one-on- } \\
\text { one discussions }\end{array}$ & $\begin{array}{l}\text { Only course- } \\
\text { wide } \\
\text { discussions }\end{array}$ & $\begin{array}{l}\text { Only course- } \\
\text { wide } \\
\text { discussions } \\
\text { through } \\
\text { commenting on } \\
\text { posts }\end{array}$ \\
\hline $\begin{array}{l}\text { Content } \\
\text { Form }\end{array}$ & $\begin{array}{l}\text { Allows the } \\
\text { use of both } \\
\text { picture and } \\
\text { video }\end{array}$ & $\begin{array}{l}\text { Mostly text } \\
\text { based with the } \\
\text { ability to use } \\
\text { video and } \\
\text { images, also } \\
\text { allows links to } \\
\text { websites }\end{array}$ & $\begin{array}{l}\text { Allows the use } \\
\text { of both picture } \\
\text { and video }\end{array}$ & $\begin{array}{l}\text { Allows the use } \\
\text { of both picture, } \\
\text { video, and text } \\
\text { with links to } \\
\text { websites }\end{array}$ & $\begin{array}{l}\text { Pictures with } \\
\text { text and links to } \\
\text { websites }\end{array}$ \\
\hline $\begin{array}{l}\text { Content } \\
\text { Origination }\end{array}$ & $\begin{array}{l}\text { Original } \\
\text { content }\end{array}$ & $\begin{array}{l}\text { Original } \\
\text { content }\end{array}$ & $\begin{array}{l}\text { Original } \\
\text { content }\end{array}$ & $\begin{array}{l}\text { Original } \\
\text { content }\end{array}$ & Public content \\
\hline Popularity & $\begin{array}{l}\text { Widely used, } \\
\text { ranked } \\
\text { number } 3 \text { in } \\
\text { social media }\end{array}$ & $\begin{array}{l}\text { Widely used, } \\
\text { ranked number } \\
1 \text { in social } \\
\text { media }\end{array}$ & $\begin{array}{l}\text { Ranked number } \\
7 \text { in social } \\
\text { media } \\
\text { platforms used }\end{array}$ & $\begin{array}{l}\text { Ranked number } \\
6 \text { in social } \\
\text { media } \\
\text { platforms used }\end{array}$ & $\begin{array}{l}\text { Ranked number } \\
8 \text { in social } \\
\text { media } \\
\text { platforms used }\end{array}$ \\
\hline
\end{tabular}




\begin{tabular}{|c|c|c|c|c|}
\hline $\begin{array}{l}\text { platforms } \\
\text { used by Gen } \\
Z \text { ( } 80 \% \\
\text { visit/use) } \\
\text { (GlobalWebI } \\
\text { ndex, 2019) }\end{array}$ & $\begin{array}{l}\text { platforms used } \\
\text { by Gen Z ( } 88 \% \\
\text { visit/use) } \\
\text { (GlobalWebInd } \\
\text { ex, 2019), but } \\
\text { students have } \\
\text { concerns over } \\
\text { privacy } \\
\text { (Gettman \& } \\
\text { Cortiio, 2015) }\end{array}$ & $\begin{array}{l}\text { (52\% visit/use) } \\
\text { (GlobalWebInd } \\
\text { ex, 2019) but } \\
\text { has a history of } \\
\text { being misused } \\
\text { by Gen Z } \\
\text { (Parker, 2019) }\end{array}$ & $\begin{array}{l}\text { by Gen } Z(64 \% \\
\text { visit/use) } \\
\text { (GlobalWebInd } \\
\text { ex, 2019) }\end{array}$ & $\begin{array}{l}\text { by Gen Z }(39 \% \\
\text { visit/use) } \\
\text { (GlobalWebInd } \\
\text { ex, 2019) }\end{array}$ \\
\hline
\end{tabular}

Sources: Author, Gettman \& Corijo (2015), GlobalWebIndex (2019), Parker (2019)

\section{Theoretical Framework}

Khan et al. (2016) surveyed introductory accounting students as to their perceptions of the use of social media for academic purposes. They found that $74 \%$ of students used social media for academic purposes primarily because it is convenient and provides easy and continuous access and it is more interesting and engaging (Khan et al., 2016). Of the students who reported not using social media for academic purposes, they had a large variety of reasons why not. For example, they felt there were limited access to academic materials on social media and information exchanged over social media could be inaccurate (Khan et al., 2016). Additionally, they found that an additional reason was the lack of academic related activities available, suggesting that students are looking to their professors to add relevant academic information to social media platforms (Khan et al., 2016). More than half the respondents noted they used social media for assignment-related activities, like discussion boards and group projects (Khan et al., 2016). The selected comments reported all discussed the ease of using the platform to share information and communicate. They also found a significant relationship between using social media to keep up to date with studies and overall GPA (Khan et al., 2016), suggesting that the use of social media outside the classroom can positively impact student performance. Since their study focused generally on social media, it's findings can reasonably be applied to an activity using Instagram. This paper will provide contextual support for their survey findings.

The activity using Instagram can be viewed as a form of supplemental instruction where the outside of class activities are completed on social media instead of inside a classroom. Supplemental instruction is "a cooperative learning model for enhancing students' understanding of course material and for improving students' overall learning and reasoning skills" (Etter, Burmeister, \& Elder, 2000). Etter et al. (2000) found in their study of supplemental instruction across 132 introductory accounting courses in 21 four-year colleges that accounting course grades were on average one-third of a letter grade higher for those who voluntarily engaged in supplemental instruction. They also found these students to be less likely to fail or withdraw from the course. The failure and withdrawal rates were each about double for non-participating students than those who participated in supplemental instruction (Etter et al., 2000). The additional outside of class, optional activities resulted in improved performance in the introductory accounting class.

Braun \& Sellers (2012) used a daily motivational quiz in their introductory accounting course to motivate students to come prepared to class and participate in class discussions. They found that just by giving a three question, conceptual quiz at the start of class, it increased student motivation. Of the 66 students in the course, 48 stated the quizzes helped prepare them for class and were responsible for their class participation (Braun \& Sellers, 2012). In addition, 79 percent of the students agreed that the daily quizzes helped them better learn the material (Braun \& Sellers, 2012). A series of three short questions to start the class had a significant improvement on student engagement and performance in the introductory accounting class.

Sargent, Faye Borthick, \& Lederberg (2011) used a series of three-minute videos throughout their introductory accounting courses to stimulate effort and performance. The voluntary short videos focused on the major concepts from each chapter with three videos per chapter. They found a 0.096 point per view increase in student exam score from Exam 1 to the Final Exam, with an average increase of just under three 
points for a student who used the videos (Sargent et al., 2011). Students also perceived the videos to be helpful with 95 percent of students citing the videos as the most useful resource for achievement in the course (Sargent et al., 2011). Their findings support that even short videos are effective in facilitating student learning.

In summary, many students are actively using social media in their personal lives, and some are using it for academic purposes (Khan et al., 2016). They are using social media as discussion boards and to organize group projects (Khan et al., 2016). However, some students are curious as to additional academic ways to use social media, and they are looking for their professors to initiate those activities (Khan et al., 2016). Supplemental instruction can be one way to bring social media to the course content. It can be beneficial in increasing both student engagement and performance, particularly in introductory accounting courses (Etter et al., 2000). Supplemental instruction does not need to be lengthy or difficult to provide value to students. Three short, conceptual questions to start class (Braun \& Sellers, 2012) or a series of videos further explaining course concepts (Sargent et al., 2011) both have seen positive outcomes for student engagement and performance. Both short videos explaining the week's content followed by short concept-based questions for students are beneficial in improving student engagement and performance in an introductory accounting course. In addition, students find an added level of convenience when using social media for academic purposes (Clements, 2015; Hurt et al., 2012; Khan et al., 2016). Using Instagram to engage students in supplemental instruction outside of the classroom using short videos and questions should improve student engagement and performance.

\section{THE ACTIVITY}

\section{Activity Goals}

The main objectives of using Instagram in the introductory accounting course are to keep students engaged in the learning process outside the classroom, create unique interactions between the professor and students, and to share professional accountant experiences. The goals for the activity are as follows:

1. Provide a unique and interesting way for students to interact with an introductory accounting course;

2. Engage students in the learning process outside of the classroom;

3. Improve overall performance in the introductory accounting course;

4. Relate to students the importance and role of accounting in business.

\section{Description of Activity}

Instagram was used as a semester-long activity in two sections of the Introductory Accounting course during the Spring 2019 semester at one university. This course includes primarily business majors with most students planning on majoring in something other than accounting. There were 68 students in the two sections of the course. The majority were second semester freshmen who have not yet declared a major. There were 11 sophomores, one junior, and one senior. There was only one student who had unofficially declared accounting as a major. I created an account on Instagram specifically for use in our accounting class and included information about the account in the syllabus, shown in Figure 1.

\section{FIGURE 1 SYLLABUS EXCERPT}

We will also be using Instagram throughout the semester to give you more information about potential careers in accounting and bringing to life our content discussions. I will also use it to award bonus points randomly throughout the semester. Participation on Instagram posts or stories is optional and will be used only for potential bonus points. The Instagram account I will be posting from is XXXX. I will not be following you back, accessing, or sharing the information from your profile. 
On the first day of classes, I explained how Instagram would be used for the course. Concerns surrounding social media as an educational tool were regarding privacy and a willingness to separate social and academic uses (Gettman \& Cortijo, 2015; Smith, 2016). To alleviate those concerns, I created an account to use solely for my accounting classes. I also made sure to ensure the students I would not be following anyone back, and I clearly stated I had no interest in doing so. Any student with a private account had the ability to deny a potential follow request, allowing them to keep their personal and academic lives separate. It was an optional activity for students to engage in but provided opportunity for extra credit. Examples of activities used on Instagram are extra practice problems, interviews with accounting professionals, sharing events happening on campus, and asking for reflection after the completion of exams. Table 2 shows a detailed list of the activities on Instagram during the semester.

TABLE 2

\section{SCHEDULE OF INSTAGRAM ACTIVITIES}

\begin{tabular}{|c|c|}
\hline January 16 & $\begin{array}{l}\text { Welcome and introduction to using Instagram for class } \\
\text { I introduced myself and shared with them the instructions for how I would work } \\
\text { bonus points. I also saved this as a Highlight. }\end{array}$ \\
\hline January 18 & $\begin{array}{l}\text { Accounting Equation story question and post } \\
\text { I asked the following questions about the accounting equation: } \\
\text { - What are the three parts of the accounting equation? } \\
\text { - Give an example of an account that would be included in each of the three } \\
\text { parts. }\end{array}$ \\
\hline January 23 & $\begin{array}{l}\text { Reminder of firms visiting on campus } \\
\text { One of the Big } 4 \text { firms that had come to our classroom was visiting on campus. I } \\
\text { did a Story post with them speaking about their event that night. }\end{array}$ \\
\hline January 26 & $\begin{array}{l}\text { Debits and Credits story question and post } \\
\text { I discussed more on debits and credits and asked the following questions: } \\
\text { - Tell me about a transaction that you went through today. Which accounts } \\
\text { - were affected by that transaction? } \\
\text { - How do they affect the accounting equation in debits and credits? } \\
\text { - What kinds of accounts increase as debits? }\end{array}$ \\
\hline January 31 & $\begin{array}{l}\text { Journal entry story question and post } \\
\text { I posted four transactions and asked the students to reply with the correct journal } \\
\text { entries. } \\
\text { 1. I started a consulting company by investing } \$ 10,000 \text { and a computer worth } \\
\$ 500 \text { into the company. } \\
\text { 2. I signed my first customer! I performed consulting services for Franklin } \\
\text { Industries. The invoice was for } \$ 15,000 \text {. They paid } \$ 10,000 \text { in cash. } \\
\text { 3. I bought supplies on account for } \$ 1,900 \text {. } \\
\text { 4. Franklin Industries paid the remaining balance. }\end{array}$ \\
\hline February 10 & $\begin{array}{l}\text { Reminder about upcoming exam } \\
\text { I posted to the story to remind them to start studying for their exam this week. }\end{array}$ \\
\hline February 19 & $\begin{array}{l}\text { Upcoming office visit to a local company and request for questions } \\
\text { I posted to the story to discuss that I would be interviewing a local Controller about } \\
\text { her job and how it pertains to accounting. I posted the poll (see Figure } 4 \text { ) to see if } \\
\text { they had any questions they wanted me to ask her. }\end{array}$ \\
\hline February 21 & $\begin{array}{l}\text { Reflection on the first exam and thoughts for improvement } \\
\text { I asked them to reflect on their study habits for the first exam and discuss things } \\
\text { they would do differently going forward throughout the semester. }\end{array}$ \\
\hline
\end{tabular}




\begin{tabular}{|c|c|}
\hline February 28 & $\begin{array}{l}\text { Public vs. Private Accounting } \\
\text { I explained the difference between public and private accounting for the upcoming } \\
\text { office visits to a local Controller and to a public accounting firm. }\end{array}$ \\
\hline March 1 & $\begin{array}{l}\text { Interview with Controller in industry } \\
\text { I went to a local company and interviewed the Controller about choosing an } \\
\text { accounting major, working in industry, and what kind of value she adds to the } \\
\text { business. Examples of questions I asked her were: } \\
\text { - What did you like about accounting as a student? } \\
\text { - What's something fun or unique about your job? } \\
\text { - Do you have any career advice for college students? }\end{array}$ \\
\hline March 7 & $\begin{array}{l}\text { Story post reminder of assignment due } \\
\text { I posted to the story to remind them they had an assignment due before Spring } \\
\text { Break. }\end{array}$ \\
\hline March $19-21$ & $\begin{array}{l}\text { Interviews with varying levels of public accountants at a local accounting firm } \\
\text { (interns, new staff, manager, and Partner) } \\
\text { I went to a local public accounting firm and interviewed staff on their experience in } \\
\text { college and in public accounting. I was able to interview a few people from the } \\
\text { firm, so I spread the interviews out over a couple of days. Examples of questions I } \\
\text { asked them were: } \\
\text { - What is it like to be (an intern/ new staff/ Partner) in a public accounting } \\
\text { firm? } \\
\text { - Why did you decide to become an accountant? } \\
\text { - What's something fun or unique about your job? } \\
\text { - Do you have any career advice for college students? }\end{array}$ \\
\hline March 26 & $\begin{array}{l}\text { Story question on how to improve studying for the second exam } \\
\text { I asked them to share with me how they were going to improve their studying for } \\
\text { the second exam. }\end{array}$ \\
\hline April 5 & $\begin{array}{l}\text { Business school event for extra credit } \\
\text { I shared with them the details of an accounting event that the business school was } \\
\text { hosting that week. }\end{array}$ \\
\hline April 12 & $\begin{array}{l}\text { Bond story question and post } \\
\text { We talked about bonds this week. I asked them the following questions: } \\
\text { - Other than by looking at the selling price, how else can you determine if a } \\
\text { bond is selling at a premium or discount? } \\
\text { - What would be the journal entry accounts for interest payment of a bond } \\
\text { that sold with a premium? } \\
\text { - At maturity, how can you determine much is paid back to the investor? }\end{array}$ \\
\hline April 17 & $\begin{array}{l}\text { Update on local firm hosting an open house event } \\
\text { The public accounting firm I had visited was hosting an open house event that } \\
\text { week. I shared the information with them. }\end{array}$ \\
\hline April 23 & $\begin{array}{l}\text { Cash flow story question and post } \\
\text { I discussed a little bit about the purpose of the Statement of Cash Flows, then asked } \\
\text { them the following questions: } \\
\text { - What are the three sections of the Statement of Cash Flows? } \\
\text { - Give an example of an account or transaction that you would find in each of } \\
\text { the three sections. }\end{array}$ \\
\hline
\end{tabular}

Most of the postings throughout the semester were content-based practice questions on the topics covered in class that week. These questions started as Instagram story video posts ${ }^{1}$, where students could respond individually to the professor with the answer. For example, the January 18 posting to the story was 
a video of myself explaining what we talked about during this week of class and asked students to respond to my video with 1) the basic accounting equation and 2) an example of an account that would be included in each of the three parts of the accounting equation. In another example, on January 31, I posted a set of four transactions that students had to reply directly to me with the correct journal entries. See Figure 2 for an example of what someone who posts a story would see. Students can reply to stories with either text, video, or picture responses. Only I can see their responses, like an email or text message conversation. My inbox shows all of the responses with each individual student as a separate message, like an email inbox, with only the two of us being able to see that conversation. The first ten students to respond correctly received five bonus points on their homework assignment (out of 100 points) for the week. Most students answered a few questions throughout the semester. The student who answered the most received bonus points seven times for a total of 35 additional points on homework assignments. This increased their overall course grade by 0.4 points. In response to some of the student answers, I individually discussed with them to work through incorrect answers and solidify their understanding of the material.

FIGURE 2

\section{STORY POSTINGS}

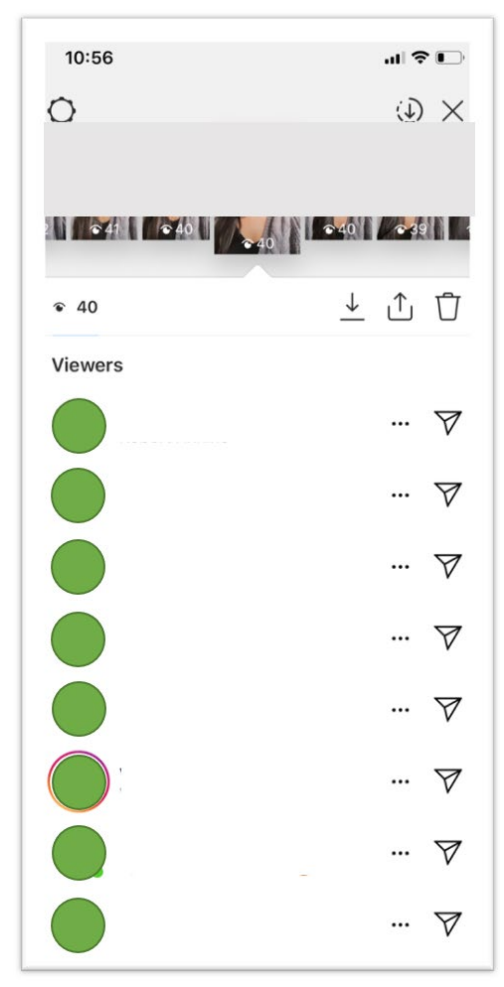

When an Instagram user posts Stories, they can go back through their stories and see who and how many people have watched them. Across the top are each of the videos that were posted to the story (in this example, it is describing bond premiums and discounts). For each 30 second clip, I can see down below who has watched that video.

After the contest was over, the correct answers and explanations were posted as a story video and also as a post to the account. Since stories are only viewable for 24 hours, I posted the correct answers and some other helpful hints for the chapter as a post to the account, which is always available for students to view and comment. See Figure 3 for an example of one of the posts to my account. 
FIGURE 3

\section{ACCOUNT POSTING WITH ANSWERS TO STORY QUESTION}

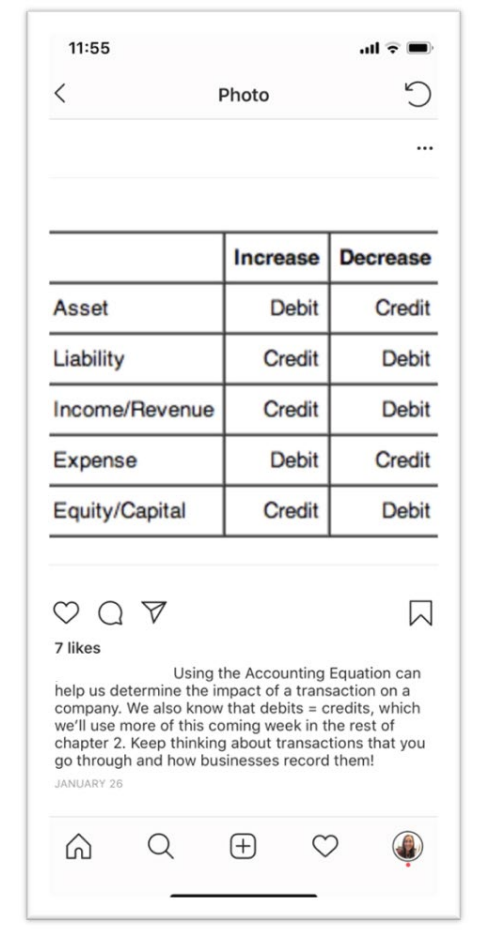

Once the activity has been completed, I posted to the account a summary of what we had discussed and what they should know about this concept. Unlike stories, this information stays visible to the student for reference later. This post stays posted in my profile. In this example, I had asked about what kinds of accounts increase as debits or credits. After the activity, I posted this summary for students to view, like, and comment.

Some of the other story video postings were interviews with accounting professionals. I recorded these interviews and posted them to the Instagram stories. They were then saved to the Highlights ${ }^{2}$ for students to view all semester. I went to a local company and interviewed their Controller, while recording the interview to post on Instagram. For example, I asked her "what is something fun or unique about your job?" and "what's important from an introductory accounting class for students who are interested in business?" I also went to a public accounting firm and interviewed on video several staff members, from interns to Partners. I asked them questions like "what did you like about accounting as a student?" and "do you have any career advice for college students?" I asked the students ahead of time on Instagram if they had any questions for the professionals through use of an Instagram polling tool. ${ }^{3}$ Figure 4 shows what someone who posts an Instagram poll will see. By using Instagram in the course, I was able to leverage the knowledge and experience of CPAs in the surrounding area without having to take time out of the class to bring them to campus or bring my students to their offices. This "virtual tour" provided a number of benefits to the students: they heard firsthand what a career in accounting is like, they saw the number of different opportunities available, they heard from varying levels of experienced professionals, they got an inside glimpse of what a firm looks like, and they heard of the value an accounting professional provides to a business. These are all things that we try to discuss with our students but hearing the information from a professional provides more truth and meaning than from the front of the classroom. 


\section{FIGURE 4 \\ THE USE OF POLLING FOR STUDENTS' QUESTIONS FOR ACCOUNTING PROFESSIONALS}

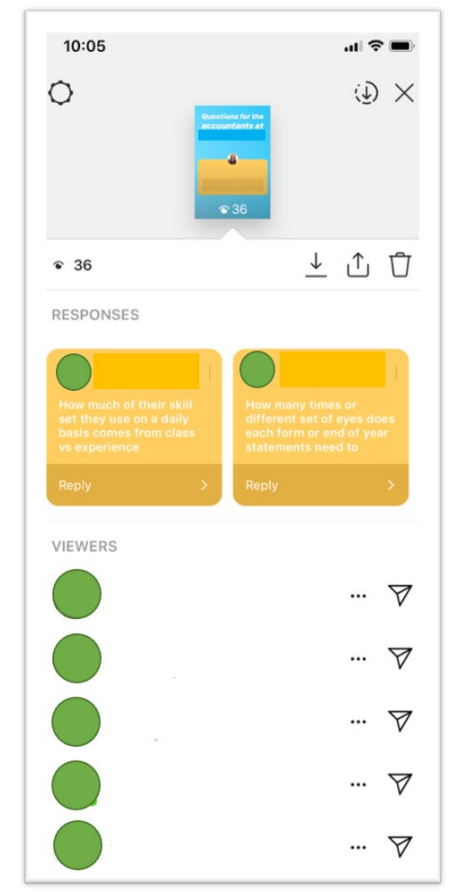

Before going to interview some local accounting professionals, I posted a poll in my stories. This poll asked the students if they had any questions they wanted me to ask the accounting professionals. You can see at the very top of the page what was posted to my story. At the bottom of the page, I can again see who has viewed the story. The boxes in the middle of the page are some of the students' responses. They had replied to the poll with questions they wanted me to ask the accounting professionals. It is all compiled in one place and makes it very easy to reference when I start my interview. This also gives them the opportunity to feel like they can interact and engage in my "virtual tours".

\section{EFFICACY OF THE ACTIVITY}

\section{Activity Goals}

At the end of the semester, students were given a survey about their use of Instagram during the course. There were additional survey questions regarding their likelihood of becoming an accounting major. Only students who reported using Instagram during the course answered questions on their experience using Instagram. Students who did not use Instagram were asked why they did not use Instagram in the course and about their likelihood of majoring in accounting.

In total, there were 52 students ( 76.5 percent of the course) that completed the survey. Table 3 reports descriptive statistics about the students in the course. The GPA was self-reported by those who took the survey. There were 37 respondents that used Instagram in the course and 15 who did not. Based on the reported descriptive statistics, those who chose to be involved in the Instagram activity generally received a higher grade in the course and had a higher overall GPA. However, based on the results of a between subjects t-test, the overall GPA was not significantly different between the two groups, $t(50)=-1.439, p=$ .156. Self-selection has been controlled for in studies of supplemental instruction by comparing the academic performance of students by using college GPA (Etter et al., 2000). Although students self-select into being involved in the activity, it appears that the selection is not influenced by their previous academic 
performance. The difference in the average final course grade between the two groups was 8.86 points. This is nearly a full letter grade difference in those who engaged in the Instagram activity and those who did not. There are some students who did not have as high of a GPA who were involved in the activity. Based on qualitative feedback, it is noted that these students were looking for ways to improve their grade, perhaps knowing that accounting would not be their best subject. Of the 37 respondents who had used Instagram, 30 of them said that they had followed the account for the bonus points, and 14 respondents said they wanted to learn more about accounting. The survey had open ended questions resulting in students replying with more than one response. The detailed count may add up to more than the number of students responding to the survey if they replied with more than one answer to a question. Of the 15 respondents who didn't use Instagram during the course, four said they didn't know about it, and five said they forgot. Of the 52 students who answered the survey, only three do not use Instagram socially. This supports the notion that Instagram is a widely used social networking platform. It may be a potential avenue to engage with students on social media without some of the privacy concerns of Facebook.

TABLE 3

\section{DESCRIPTIVE STATISTICS}

\begin{tabular}{|l|c|c|c|c|c|c|c|}
\hline & $\mathrm{n}$ & $\begin{array}{l}\text { Average } \\
\text { Course } \\
\text { Grade }\end{array}$ & $\begin{array}{l}\text { Std } \\
\text { Dev }\end{array}$ & $\begin{array}{l}\text { Percentage } \\
\text { with GPA } \\
2.0-2.5\end{array}$ & $\begin{array}{l}\text { Percentage } \\
\text { with GPA } \\
2.5-3.0\end{array}$ & $\begin{array}{l}\text { Percentage } \\
\text { with GPA } \\
3.0-3.5\end{array}$ & $\begin{array}{l}\text { Percentage } \\
\text { with GPA } \\
3.5-4.0\end{array}$ \\
\hline $\begin{array}{l}\text { Instagram } \\
\text { Followers }\end{array}$ & 37 & 83.19 & 12.31 & $2.70 \%$ & $18.92 \%$ & $29.73 \%$ & $48.65 \%$ \\
\hline $\begin{array}{l}\text { Non- } \\
\text { Followers }\end{array}$ & 15 & 74.33 & 14.15 & $6.67 \%$ & $20.00 \%$ & $53.33 \%$ & $20.00 \%$ \\
\hline $\begin{array}{l}\text { Total from } \\
\text { Survey } \\
\text { Respondents }\end{array}$ & 52 & 80.63 & 13.36 & $3.85 \%$ & $19.23 \%$ & $36.54 \%$ & $40.38 \%$ \\
\hline $\begin{array}{l}\text { Total Non- } \\
\text { respondents }\end{array}$ & 16 & 75.00 & 10.35 & & & & \\
\hline $\begin{array}{l}\text { Course } \\
\text { Totals }\end{array}$ & 68 & 79.31 & 12.87 & & & & \\
\hline
\end{tabular}

Note: Since GPA was self-reported data obtained from respondents of the survey, this information is not available from the students in the class who did not respond to the survey.

Table 4 reports the survey responses for the Instagram users. The survey had students rate their agreement with statements following a 5-point Likert scale, with 1 being strongly disagree and 5 being strongly agree. All questions, except those relating to a future in accounting, received high scores above a 3.0. The overall response to the activity is positive. The questions with the highest scores were for the unique opportunity the use of Instagram provided them to engage with the course content (mean of 4.16) and for its continued use (mean of 4.38). The positive results for the activity's continued use supports the results of Khan et al. (2016) that students are looking for academic related ways to use social media. When provided with an academic use of social media, students find using Instagram for coursework to be an enjoyable experience (mean of 3.95). Overall, students enjoyed the unique way to interact with the course content and were more actively engaged in the learning process. Of the respondents who used Instagram in the course, nearly 92 percent agreed or strongly agreed that it should continue to be used. 
TABLE 4

SURVEY RESPONSES OF INSTAGRAM USERS

\begin{tabular}{|c|c|c|}
\hline Survey Questions & Mean & Std Dev \\
\hline \multicolumn{3}{|l|}{$\begin{array}{l}\text { Goal 1: Provide a unique and interesting way for students to interact with } \\
\text { an introductory accounting course }\end{array}$} \\
\hline I enjoyed listening to the stories and reading the posts on Instagram. & 3.95 & 0.62 \\
\hline $\begin{array}{l}\text { The Instagram stories and posts helped me feel more positively towards the } \\
\text { accounting course. }\end{array}$ & 3.86 & 0.71 \\
\hline $\begin{array}{l}\text { I found that the Instagram stories and posts made the topic of accounting } \\
\text { more interesting. }\end{array}$ & 3.65 & 0.92 \\
\hline $\begin{array}{l}\text { The Instagram stories and posts provided a unique way for me to engage } \\
\text { with the content of the course. }\end{array}$ & 4.16 & 0.87 \\
\hline \multicolumn{3}{|l|}{ Goal 2: Engage students in the learning process outside of the classroom } \\
\hline $\begin{array}{l}\text { The stories and posts on Instagram made me feel more actively involved in } \\
\text { the learning process. }\end{array}$ & 3.86 & 0.82 \\
\hline $\begin{array}{l}\text { As a result of using Instagram, I was more engaged in the accounting } \\
\text { course than I would have been otherwise. }\end{array}$ & 3.54 & 1.19 \\
\hline \multicolumn{3}{|l|}{$\begin{array}{l}\text { Goal 3: Improve overall performance in the introductory accounting } \\
\text { course }\end{array}$} \\
\hline $\begin{array}{l}\text { The Instagram stories and posts helped me to better understand the } \\
\text { accounting course topics. }\end{array}$ & 3.59 & 1.01 \\
\hline $\begin{array}{l}\text { The Instagram stories and posts helped me to better understand the } \\
\text { accounting course topics that I found to be difficult. }\end{array}$ & 3.30 & 1.05 \\
\hline $\begin{array}{l}\text { Being involved in the Instagram stories and posts had a positive effect on } \\
\text { my overall course grade. }\end{array}$ & 3.62 & 1.23 \\
\hline \multicolumn{3}{|l|}{$\begin{array}{l}\text { Goal 4: Relate to students the importance and role of accounting in } \\
\text { business }\end{array}$} \\
\hline $\begin{array}{l}\text { As a result of the Instagram stories and posts, I was better able to } \\
\text { understand the job of an accountant. }\end{array}$ & 3.76 & 0.68 \\
\hline $\begin{array}{l}\text { The Instagram stories and posts helped me to value the role of an } \\
\text { accountant in a business environment. }\end{array}$ & 3.57 & 0.96 \\
\hline \multicolumn{3}{|l|}{ Student Perceptions: } \\
\hline $\begin{array}{l}\text { The Instagram stories and posts positively influenced me to consider a } \\
\text { major or career in accounting. }\end{array}$ & 2.92 & 1.14 \\
\hline Prior to this class, I was considering becoming an accounting major. & 1.78 & 1.26 \\
\hline $\begin{array}{l}\text { After completing this class, I am considering becoming an accounting } \\
\text { major. }\end{array}$ & 2.08 & 1.00 \\
\hline $\begin{array}{l}\text { The interviews with professionals and other information provided to me on } \\
\text { the Instagram stories were helpful in making my decision to major in } \\
\text { accounting. }\end{array}$ & 2.68 & 1.06 \\
\hline Instagram should continue to be used in this course. & 4.38 & 0.72 \\
\hline $\begin{array}{l}\text { The Instagram stories and posts were a valuable tool for me to utilize in this } \\
\text { course. }\end{array}$ & 3.89 & 0.81 \\
\hline
\end{tabular}

Results reported on a 5-point Likert scale, with 1 being strongly disagree and 5 being strongly agree

The lowest scores on the survey were for the potential of an accounting major or career. One student noted in the survey, "I was never going to be an accountant, so my negative responses are not due to any use of Instagram, just that I am not particularly interested in accounting". This opinion likely applies to more students in the course as well. There were 23 of the 52 respondents who answered strongly disagree 
to considering becoming an accounting major both prior to and after completing the class. All students taking the survey, regardless of their use of Instagram, answered questions related to the likelihood of them majoring in accounting before and after the course. Our goal is to present to students the opportunities that accounting can provide them and hope to attract those who are interested in accounting. That doesn't mean that all students will become accounting majors, nor should that be our goal. There were 15 students whose score increased after completion of the course, with one student's response jumping from a one to a five. Even if they were not particularly interested in a future career in accounting, they still found this a worthwhile activity and suggested it be used in the future.

Table 5 presents the correlation between course grade, section of the course, year in school, overall GPA, if they followed the Instagram account, and their perceptions of majoring in accounting both before and after the course. Variable definitions are included in Exhibit 1 of the Appendix. There is a strong correlation between course grade and both overall GPA and likelihood of majoring in accounting after completion of the course. Neither of those outcomes is ultimately very surprising. If students perform well in all subjects and have a high overall GPA, it is likely they will continue to perform well in another course, resulting in a high course grade. In addition, if students perform well in the first accounting course, it is likely they are more willing to consider a future major in that subject area. Following the Instagram account, however, does not have a strong correlation with any of the other variables. This finding is in contrast of the strong relationship between overall GPA and use of social media to keep up with academics found by Khan et al. (2016). Perhaps this suggests that high GPA students would be involved in social media to keep up with their coursework, while lower GPA students are involved in this activity, but not other social media activities that would be considered keeping up with coursework. This provides additional, limited evidence to reduce the risk of self-selection bias involved in the voluntary activity. Students who self-select are not necessarily those with the highest GPAs or course grades. It is not just the strong students or just the weak students who followed the account but a mix of some of both groups of students. By offering bonus points for active participants, the activity is attractive to both higher and lower GPA students. Although there is still a risk of self-selection bias due to the voluntary nature of the activity, it doesn't appear to have attracted only a certain type of student to the activity.

TABLE 5

PEARSON CORRELATIONS

\begin{tabular}{|c|c|c|c|c|c|c|c|}
\hline & $\begin{array}{l}\text { Course } \\
\text { Grade }\end{array}$ & Section & Year & $\begin{array}{c}\text { Overall } \\
\text { GPA }\end{array}$ & Follow & $\begin{array}{l}\text { Prior } \\
\text { Major }\end{array}$ & $\begin{array}{l}\text { After } \\
\text { Major }\end{array}$ \\
\hline Course Grade & 1.000 & -.047 & .106 & .744 & .303 & .334 & .633 \\
\hline Section & -.047 & 1.000 & .207 & -.044 & -.314 & .032 & .111 \\
\hline Year & .106 & .207 & 1.000 & -.043 & -.067 & .271 & .108 \\
\hline Overall GPA & .744 & -.044 & -.043 & 1.000 & .199 & .097 & .372 \\
\hline Follow & .303 & -.314 & -.067 & .199 & 1.000 & -.069 & -.044 \\
\hline Prior Major & .334 & .032 & .271 & .097 & -.069 & 1.000 & .680 \\
\hline After Major & .633 & .111 & .108 & .372 & -.044 & .680 & 1.000 \\
\hline
\end{tabular}

See Appendix for Variable Definitions.

To further investigate the relationship between course grade and following the Instagram account, I performed regression analysis controlling for variables that are likely to affect course grade. Table 6 reports the results. The adjusted $\mathrm{R}^{2}$ is .723 for the model. Overall GPA and the likelihood of majoring in accounting after the course are both highly significant $(p=.000)$. Additionally, following the Instagram account has a significant impact on course grade $(p=.011)$, even after controlling for overall GPA and likelihood of majoring in accounting. If a given student were to follow the Instagram account, it would lead to a 6.180 increase in their final course grade. This is slightly higher than the approximately three point grade increase 
found by Etter et al. (2000) for supplemental instruction. This could mean that using an interesting platform like social media to engage students in supplemental instruction could lead to a higher grade point increase in participants. However, further research should more fully investigate the impact of social media supplemental instruction on academic performance. The difference in final course grade is both statistically significant and has a letter grade impact, adding support to the value of this activity.

\section{TABLE 6 \\ THE ASSOCIATION BETWEEN FOLLOWING ON INSTAGRAM AND COURSE GRADE}

\begin{tabular}{lcc} 
& \multicolumn{3}{c}{ Course Grade } \\
\cline { 2 - 3 } Follow & Coef. & t-stat \\
& .212 & $2.662^{* *}$ \\
Control Variables & & \\
Section & -.031 & -.386 \\
Year & .113 & 1.433 \\
Overall GPA & .535 & $6.380^{* * *}$ \\
Prior Major & -.054 & -.501 \\
After Major & .472 & $4.175^{* * *}$
\end{tabular}

Model Fit

Adjusted $\mathrm{R}^{2}$

See Appendix for Variable Definitions. ***,**, and * indicate significant at $1 \%, 5 \%$, and 10\% respectively

\section{Student Perceptions}

Some of the highest scores on the survey were for the continued use of Instagram in the course (mean of 4.38) and Instagram being a valuable tool to utilize in the course (mean of 3.89). The students perceive this to be a worthwhile activity that should continue to be used in the course. Included in the survey was also a section for students to share their open-ended responses on using Instagram as part of the class. Most of the responses were overwhelmingly positive, with some suggestions for improvement. Below are some of the students' responses:

- It's fun and different and really nice to offer bonus points

- I think that using Instagram was a great new way to connect with students.

- Thought the use of Instagram was super cute!

- It was very helpful since it required me to study harder in order to get the extra credit questions correct.

- Instagram was a good tool utilized to help keep me involved and engaged with the topic at hand. I would recommend more professors try this out in their own methods.

- None of my other professors have used Instagram in this way, but I think it is a very beneficial tool and think that it should continue to be used!

- It was very helpful and should definitely be used more

- I really enjoyed the interview with the professionals

- I find it to be a good source of extra information and practice.

- It was very fun and entertaining tool for education

- It was a fun and great way to help myself and other students engage in the course and boost their grades.

- Thought it was a good chance for students to learn more 


\section{Limitations}

As this was an optional out of class activity that spanned the length of the semester, there is a risk of self-selection bias. Those who are interested in accounting or are looking for bonus points are likely to be the ones who opt into the activity. However, the results of a between subjects t-test find no significant difference in overall GPA between those who were involved and those who were not involved in the Instagram activity. Using GPA and academic performance to control for self-selection bias in supplemental instruction studies is common (Etter et al., 2000). Additionally, the correlations in Table 5 report there to be a weak correlation between following the account and course grade and almost no correlation with their perceptions of majoring in accounting before or after completion of the course. This provides additional, limited evidence to support that no one certain type of student was interested in the activity. Bosch (2009) found that when posting was optional for students, there was an increase in participation. Wang, Woo, Quek, Yang, \& Liu (2012) found that the postings in an optional Facebook group were nearly four times the number of postings on the required WebCT platform, with the Facebook postings raising more complex issues and more detailed replies. Even with the potential for self-selection bias, research supports there to be an increase in participation when the activity is voluntary. I would continue to suggest the activity be carried out as optional. Future research should use control groups and random assignment to alleviate the concern of self-selection bias.

This activity takes dedication on the part of the professor. Posting once per week throughout the semester takes about 30 minutes per week to come up with a question, record and post the question on the stories, read and reply to students' responses, post the answer in the stories and an account post, and compile bonus points. However, the more comfortable an instructor becomes with the platform and sharing stories, the less time it will take. Being vulnerable in front a camera, being yourself, and sharing yourself with your students is something they generally appreciate and enjoy, based on their qualitative feedback. There are some tasks that can be passed off to a TA, if you have one available, such as replying to students' responses and tallying the bonus points. They can also likely assist with the recording and posting of stories if a professor is not comfortable with the use of Instagram. The assistance of a TA would likely leave the professor with about 15 minutes of work per week to record and post the questions. To save time later in the semester, videos can be recorded and saved to the camera roll ahead of time. Any text for postings can also be saved to the Notes app then copied and pasted to a post. There are also paid apps available, such as Hootsuite, that allow for the scheduling of posts ahead of time. In addition, the same videos and postings can be used year after year, significantly reducing the set-up time.

\section{CONCLUSION}

This paper specifically focuses on student engagement in an Introductory Accounting course. However, it is also important to us as a profession to continue to attract accounting majors. According to the AICPA 2019 Trends Report, the number of total accounting degrees awarded have been on a steady decline since $2011-2012$ (AICPA, 2019). Since most students are taking Introductory Accounting early in their careers, likely before they have declared a major, we have an opportunity to present to them all the benefits of accounting as a profession. Future research could study if using Instagram in a course added any value in attracting students to an accounting major. Another concern in the first accounting course is the number of students who withdraw or fail the course. Future research could investigate if the use of Instagram had any impact on the number of students who dropped out or failed.

Although this paper used Instagram in the Introductory Accounting course, this activity could easily be adapted to upper-level accounting courses. Content-based questions could be modified to fit the topic of the course, like audit or tax. Interviews with professionals could be focused on a future career in those subject areas. It would be especially interesting to use Instagram in an online or hybrid course. Since the students do not meet frequently in person, or at all, Instagram could be used as a method to build community in those courses. Further research should investigate the impact of social media uses in upper level and nontraditional courses. 
The use of Instagram outside of the classroom is a unique and fun way to present information to students whose lives are centered around technology and social media. Posting story questions on content covered in class gives students another chance to test their knowledge. It also offers the opportunity for one-on-one discussions about incorrect answers or questions the students may have. By including interviews from accounting professionals, students get a look into what a career in accounting would mean for them. This introductory class is usually centered around journal entries and understanding the impact of transactions on the financial statements. Students then think that life as an accountant means constantly writing journal entries all day. In reality, there is opportunity for creative thinking and strategy that we don't always have the time to convey in the first accounting class. Overall, students find the use of Instagram unique, engaging, and a fun way to interact with accounting and suggest its continued use.

\section{ENDNOTES}

1. To learn more about Instagram Stories and how they work, this is an article from Instagram: https://instagrampress.com/blog/2016/08/02/introducing-instagram-stories/

2. To learn more about Instagram Story Highlights, this is an article from Instagram: https:/instagrampress.com/blog/2017/12/05/introducing-stories-highlights-and-stories-archive/

3. To learn more about Instagram polls, this is an article from Instagram: https://instagrampress.com/blog/2017/10/03/introducing-polls-in-instagram-stories/

\section{REFERENCES}

Abbott, J.I., \& Palatnik, B.R. (2018). Students' perceptions of their first accounting class: Implications for instructors. Accounting Education, 27(1), 72-93.

AICPA. (2019). 2019 Trends in the supply of accounting graduates and the demand for public accounting recruits. Retrieved from https://www.aicpa.org/interestareas/accountingeducation/ newsandpublications/aicpa-trends-report.html

Al-Bahrani, A., \& Patel, D. (2015). Incorporating Twitter, Instagram, and Facebook in economics classrooms. Journal of Economic Education, 46(1), 56-57.

Arquero, J.L., \& Romero-Frías, E. (2013). Using social network sites in higher education: An experience in business studies. Innovations in Education and Teaching International, 50(3), 238-249.

Bosch, T.E. (2009). Using online social networking for teaching and learning: Facebook use at the University of Cape Town. Communication, 35(2), 185-200.

Braun, K.W., \& Sellers, R.D. (2012). Using a "daily motivational quiz" to increase student preparation, attendance, and participation. Issues in Accounting Education, 27(1), 267-279.

Bryson, C., \& Hand, L. (2007). The role of engagement in inspiring teaching and learning. Innovations in Education and Teaching International, 44(4), 349-362.

Cain, J., \& Policastri, A. (2011). Using Facebook as an informal learning environment. American Journal of Pharmaceutical Education, 75(10), 1-8.

Carini, R.M., Kuh, G.D., \& Klein, S.P. (2006). Student engagement and student learning: Testing the linkages. Research in Higher Education, 47(1), 1-32.

Chapman, E. (2003). Alternative approaches to assessing student engagement rates. Practical Assessment, Research and Evaluation, 8(13).

Clements, J.C. (2015). Using Facebook to enhance independent student engagement: A case study of first-year undergraduates. Higher Education Studies, 5(4).

Coates, H. (2005). The value of student engagement for higher education quality assurance. Quality in Higher Education, 11(1), 25-36.

D’Aquila, J.M., Wang, D., \& Mattia, A. (2019). Are instructor generated YouTube videos effective in accounting classes? A study of student performance, engagement, motivation, and perception. Journal of Accounting Education, 47, 63-74. https://doi.org/10.1016/j.jaccedu.2019.02.002 
Dabbagh, N., \& Kitsantas, A. (2012). Personal Learning Environments, social media, and self-regulated learning: A natural formula for connecting formal and informal learning. Internet and Higher Education, 15(1), 3-8.

Dyson, B., Vickers, K., Turtle, J., Cowan, S., \& Tassone, A. (2015). Evaluating the use of Facebook to increase student engagement and understanding in lecture-based classes. Higher Education, 69(2), 303-313.

Etter, E.R., Burmeister, S.L., \& Elder, R.J. (2000). Improving student performance and retention via supplemental instruction. Journal of Accounting Education, 18(4), 355-368.

Evans, C. (2014). Twitter for teaching: Can social media be used to enhance the process of learning? British Journal of Educational Technology, 45(5), 902-915.

Gettman, H.J., \& Cortijo, V. (2015). "Leave me and my Facebook alone!" Understanding college students' relationship with Facebook and its use for academic purposes. Georgia Educational Researcher, 9(1).

GlobalWebIndex. (2019). Gen Z: Examining the attitudes and digital behaviors of internet users aged 1620. Retrieved from www.globalwebindex.net

Hollyhead, A., Edwards, D.J., \& Holt, G.D. (2012). The use of virtual learning environment (VLE) and social network site (SNS) hosted forums in higher education: A preliminary examination. Industry and Higher Education, 26(5), 369-379.

Holmes, A.F., \& Rasmussen, S.J. (2018, April). Using Pinterest to stimulate student engagement, interest, and learning in managerial accounting courses. Journal of Accounting Education, 43, 43-56.

Hornik, S., \& Thornburg, S. (2010). Really engaging accounting: Second LifeTM as a learning platform. Issues in Accounting Education, 25(3), 361-378.

Hurt, N.E., Moss, G., Bradley, C., Larson, L., Lovelace, M., Prevost, L., . . Camus, M. (2012). The 'Facebook' effect: College students' perceptions of online discussions in the age of social networking. International Journal for the Scholarship of Teaching and Learning, 6(2).

Junco, R. (2012). Too much face and not enough books: The relationship between multiple indices of Facebook use and academic performance. Computers in Human Behavior, 28(1), 187-198.

Junco, R., Elavsky, C.M., \& Heiberger, G. (2013). Putting twitter to the test: Assessing outcomes for student collaboration, engagement and success. British Journal of Educational Technology, 44(2), 273-287.

Junco, R., Heiberger, G., \& Loken, E. (2011). The effect of Twitter on college student engagement and grades. Journal of Computer Assisted Learning, 27(2), 119-132.

Khan, T., Kend, M., \& Robertson, S. (2016). Use of social media by university accounting students and its impact on learning outcomes. Accounting Education, 25(6), 534-567.

Kirschner, P.A., \& Karpinski, A.C. (2010). Facebook and academic performance. Computers in Human Behavior, 26(6), 1237-1245.

Kuh, G.D. (2003). What we're learning about student engagement from NSSE: Benchmarks for effective educational practices. Change, 35(2), 24-32.

Kuh, G.D., Kinzie, J., \& Buckley, J.A. (2006). What matters to student success: A review of the literature. National Symposium on Postsecondary Student Success: Spearheading a Dialog on Student Success. Retrieved from https://nces.ed.gov/npec/pdf/kuh_team_report.pdf

Lambić, D. (2016). Correlation between Facebook use for educational purposes and academic performance of students. Computers in Human Behavior, 61, 313-320.

Lee, J.S. (2014). The relationship between student engagement and academic performance: Is it a myth or reality? Journal of Educational Research, 107(3), 177-185.

Lowe, B., \& Laffey, D. (2011). Is twitter for the birds? Using twitter to enhance student learning in a marketing course. Journal of Marketing Education, 33(2), 183-192.

Manca, S., \& Ranieri, M. (2016). "Yes for sharing, no for teaching!": Social Media in academic practices. Internet and Higher Education, 29, 63-74.

Parker, W. (2019). The dark side of Snapchat and teens. Retrieved from https://www.verywellfamily.com/what-is-snapchat-and-its-use-1270338 
Paul, J.A., Baker, H.M., \& Cochran, J.D. (2012). Effect of online social networking on student academic performance. Computers in Human Behavior, 28(6), 2117-2127.

Roblyer, M.D., McDaniel, M., Webb, M., Herman, J., \& Witty, J.V. (2010). Findings on Facebook in higher education: A comparison of college faculty and student uses and perceptions of social networking sites. Internet and Higher Education, 13(3), 134-140.

Sakr, M. (2019). 'It just opened my eyes a bit more': student engagement with Instagram to develop understanding of complex concepts. Teaching in Higher Education, 0(0), 1-14.

Sargent, C.S., Borthick, A.F., \& Lederberg, A.R. (2011). Improving retention for principles of accounting students: Ultra-short online tutorials for motivating effort and improving performance. Issues in Accounting Education, 26(4), 657-679.

Sheeran, N., \& Cummings, D.J. (2018). An examination of the relationship between Facebook groups attached to university courses and student engagement. Higher Education, 76(6), 937-955.

Smith, E.E. (2016). "A real double-edged sword": Undergraduate perceptions of social media in their learning. Computers and Education, 103, 44-58.

Top, E. (2012). Blogging as a social medium in undergraduate courses: Sense of community best predictor of perceived learning. Internet and Higher Education, 15(1), 24-28.

Wang, Q., Woo, H.L., Quek, C.L., Yang, Y., \& Liu, M. (2012). Using the Facebook group as a learning management system: An exploratory study. British Journal of Educational Technology, 43(3), 428-438.

Yu, A.Y., Tian, S.W., Vogel, D., \& Chi-Wai Kwok, R. (2010). Can learning be virtually boosted? An investigation of online social networking impacts. Computers and Education, 55(4), 1494-1503.

\section{APPENDIX: VARIABLE DEFINITIONS}

\begin{tabular}{|c|c|}
\hline Variable & Description \\
\hline Course Grade & Numerical grade received in the course at the end of the semester \\
\hline Follow & $\begin{array}{l}\text { Dummy variable representing if the student followed the professor's Instagram } \\
\text { account during the semester - } 1 \text { if they followed, } 0 \text { if not }\end{array}$ \\
\hline Section & Dummy variable representing the section of the course the student was enrolled in \\
\hline Year & $\begin{array}{l}\text { Categorical variable representing the year in college of the student - } 0 \text { for Freshman, } \\
1 \text { for Sophomore, } 2 \text { for Junior, } 3 \text { for Senior }\end{array}$ \\
\hline Overall GPA & $\begin{array}{l}\text { Categorical variable representing the student's overall GPA - } 0 \text { for a range between } \\
2.0 \text { and } 2.5,1 \text { for between } 2.5 \text { and } 3.0,2 \text { for between } 3.0 \text { and } 3.5 \text {, and } 3 \text { for between } \\
3.5 \text { and } 4.0 \text {. }\end{array}$ \\
\hline Prior Major & $\begin{array}{l}\text { Student's self-reported likelihood of majoring in accounting prior to completion of } \\
\text { the course measured on a } 5 \text {-point Likert scale with } 1 \text { being strongly disagree and } 5 \\
\text { being strongly agree }\end{array}$ \\
\hline After Major & $\begin{array}{l}\text { Student's self-reported likelihood of majoring in accounting after completion of the } \\
\text { course measured on a } 5 \text {-point Likert scale with } 1 \text { being strongly disagree and } 5 \text { being } \\
\text { strongly agree }\end{array}$ \\
\hline
\end{tabular}

